\title{
Cucumber production under organic cultivation in response to biofertilizer application
}

\author{
Gabriela da Silva Tamwing*(D), Sebastião Elviro de Araújo Neto미, Greta Marino (D), \\ Andressa Sampaio Marreiro (D), Regina Lúcia Félix Ferreira(D)
}

Federal University of Acre, Rio Branco, Brazil

*Corresponding author, e-mail: gaby_tamwing@hotmail.com

\begin{abstract}
Cucumber is a vegetable species of high socioeconomic importance, whose fruits are consumed in all Brazilian regions. However, the knowledge of its organic production is still incipient. In this perspective, this study aimed to evaluate the productive performance of the Aodai cucumber under organic cultivation in response to the application of biofertilizer via soil and leaves. The experiment was conducted in the Seridó Ecological Site, Rio Branco, AC, by adopting a randomized block design in a $6 \times 2$ factorial arrangement, with four replications and eight plants per experimental unit. The treatments consisted of six concentrations of biofertilizer $(0,1,2,3,4$, and $5 \%)$ diluted in water, applied via foliar spraying, combined with the presence or absence of its pure application in the soil, with both methods applied at 7, 14,21, and 28 days after sowing. The fertilizer was also applied in the soil at sowing. At the end of each harvest, the fruits were divided into two quality categories (classes 1 and 2), and then the following variables were evaluated: number of fruits per plant, mean fruit mass, yield, fruit diameter, and fruit length. There was no significant interaction of the biofertilizer application via foliar spraying or soil for any of the variables. The biofertilizer application via foliar spraying promoted a significant increase in the number of marketable fruits per plant, mean mass of total fruits, and marketable and total yields. The $3 \%$ concentration of biofertilizer diluted in water and applied on the leaves is the most efficient method to increment the cucumber yield.
\end{abstract}

Keywords: Cucumis sativus L., organic fertilization, yield, quality

\section{Introduction}

The Brazilian production of cucumber surpasses 200,000 t per year, especially in the Southeast region (58.5\%), followed by the South (17\%) and North regions (11\%) (IBGE, 2017). This production relies on the excessive use of mineral fertilizers and synthetic agrochemicals, which, besides burdening production costs, leads to processes of physical, chemical, and biological degradation of the soil, as well as contamination of air, water, and of the food itself (Cavalcante et al., 2019).

Cucumber has stood out in the market of organic products, and its yields in this system have reached from 37.55 t ha $^{-1}$ (Silva et al., 2011 ) to 40.16 t ha $^{-1}$ (Sediyama et al., 2014a) for the ginoic hybrid grown under direct sunlight, and up to 56.71 t ha $^{-1}$ for the Japanese cucumber grown in plant nursery (Antonio et al., 2017).

New alternatives are required to mitigate the negative effects of conventional agriculture and produce high-quality products without toxic residues (Chiconato et al., 2013; Sediyama et al., 2014b). In this perspective, the use of biofertilizers constitutes an efficient and low-cost practice for nutritional supplementation in Olericulture, an activity that requires a high amount of nutrients in a short time range (Araújo Neto \& Ferreira, 2019).

Besides providing macro and micronutrients, biofertilizers act by improving the physical (Mellek et al., 2010) and biological properties of the soil (Wang et al., 2019). In the plant, they promote increments in production, quality, and the synthesis of defense metabolisms for phytosanitary control (Ghosh et al., 2015; Kumar et al., 2018; Rampelotto et al., 2013).

The increment in yield with the use of biofertilizers occurs in several species, as observed for the okra (Abelmos chusesculentus) (Nunes et al., 2018), watermelon (Citrullus lanatus) (Dutra et al., 2016), melon (Santos et al., 2019), onion (Allium cepa) (Nobile et al., 2012), and pepper 
crops (Capsicum baccatum var., pendulum L.) (Oliveira et al., 2014).

Several factors influence the response of the crops to biofertilizer application: composition, method of preparation, the form of application, and concentration of the fermentative (Silva et al., 2012; Santos et al., 2014; Santos et al., 2017). Biofertilizers can be applied via foliar spraying (Santos et al., 2013), on the soil (Aguiar et al., 2017), and via fertigation (Gomes et al., 2015).

In the literature, studies that evaluate the effects of biofertilizer application on the productive performance of the cucumber crop are still scarce. Antonio et al. (2017) observed that two biofertilizer applications at 15\%, via dripping, promoted the best responses in Japanese cucumber production, demonstrating that the crop responds positively to organic fertilization. In this context, this study aimed to evaluate the productive performance of the cucumber group Aodai under organic fertilization in response to biofertilizer application via soil and leaves.

\section{Material and Methods}

The experiment was performed in the Seridó Ecological Site, located in Rio Branco, AC, latitude $9^{\circ} 53^{\prime}$ $16^{\prime \prime}$ S, longitude $67^{\circ} 49^{\prime} 11$ ' 'W, and elevation of $170 \mathrm{~m}$, in the period from June to October 2019. The region presents a hot and humid climate of the Am type, according to the classification by Köppen, with mean annual temperatures around $25.3^{\circ} \mathrm{C}$, air relative humidity of $84 \%$, and mean annual rainfall of 2,247 $\mathrm{mm}_{\text {year- }}$ (INMET, 2019).

The soil of the experimental area is classified as a plinthic allitic Yellow Argisol. The chemical characterization of the soil at the 0 to $20 \mathrm{~cm}$ depth layer presented the following results: $\mathrm{pH}\left(\mathrm{H}_{2} \mathrm{O}\right)=6.1 ; O . M .=22 \mathrm{~g} \mathrm{dm}^{-3} ; \mathrm{P}=6$ $\mathrm{mg} \mathrm{dm}{ }^{-3} ; \mathrm{K}=0.5 \mathrm{mmol}_{\mathrm{c}} \mathrm{dm}^{-3} ; \mathrm{Ca}=30 \mathrm{mmol}_{\mathrm{c}} \mathrm{dm}^{-3} ; \mathrm{Mg}^{-3}$ $12 \mathrm{mmol}_{\mathrm{c}} \mathrm{dm}^{-3} ; \mathrm{Al}=1 \mathrm{mmol}_{\mathrm{c}} \mathrm{gm}^{-3} ; \mathrm{H}+\mathrm{Al}=18 \mathrm{mmol}_{\mathrm{c}} \mathrm{dm}^{-3}$; according to ICASA (Instituto Campineiro de Análise de Solo e Adubo Ltda).

The experimental design was in randomized blocks, in a $6 \times 2$ factorial arrangement, with four replications and eight plants per experimental unit. The treatments consisted of six foliar concentrations of biofertilizer 10 , $1,2,3,4$, and $5 \%$ ) diluted in water, combined with the presence or absence of the formulation applied via soil.

The biofertilizer was obtained by semi-aerobic fermentation, in contact with air, in plastic barrels with a $200 \mathrm{~L}$ capacity, which were covered in order to avoid the inflow of rainwater. For the preparation, $48 \mathrm{~L}$ of fresh grass, $6 \mathrm{~kg}$ of thermophosphate, $10 \mathrm{~L}$ of ash, and $6 \mathrm{~kg}$ of organic topsoil were used, complementing the final volume with water. At the end of the process, 30 days after the preparation, samples of the biofertilizer were collected and sent to ICASA for the chemical analyses, which presented the following results: 4.8 of $\mathrm{pH} ; 0.19 \%$ of $\mathrm{N} ; 0.14 \%$ of $\mathrm{P}_{2} \mathrm{O}_{5} ; 0.19 \%$ of $\mathrm{K} ; 0.40 \%$ of $\mathrm{Ca}$, and 0.38 of $\mathrm{Mg}$.

For the preparation of the area, harrowing was performed with the aid of a micro-tractor, and afterward, planting beds with $30 \mathrm{~m}$ length, $0.8 \mathrm{~m}$ width, and 0.15 $\mathrm{m}$ height were prepared, covered with a double-sided mulching plastic (black/white) with $150 \mu$ thickness.

The fertilization and liming of the planting beds was performed based on soil analyses and the recommendation for the crop. Base saturation was increased to $75 \%$ by applying $500 \mathrm{~kg} \mathrm{ha}^{-1}$ of limestone (PRNT of 95\%), and at planting, fertilization was performed using $15 \mathrm{tha}^{-1}$ of organic compost and $1.40 \mathrm{tha}^{-1}$ of thermophosphate. Via topdressing, 40 days after sowing, $250 \mathrm{~kg}$.ha-1 of $\mathrm{K}_{2} \mathrm{O}$ was applied, equivalent to $485 \mathrm{~kg}$.ha?' of potassium sulfate, for the treatments without the

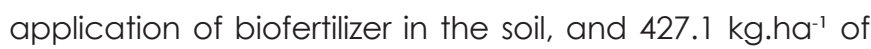
potassium sulfate plus $63.3 \mathrm{~kg} \cdot \mathrm{ha}^{-1}$ of biofertilizer, aiming at leveling the $\mathrm{K}$ levels between the plots fertilized with the biofertilizer and those without fertilization.

Sowing was performed directly on the planting beds by depositing four seeds of the Aladdin Fl hybrid per planting hole. Seven days after sowing, thinning was performed by allowing one plant per hole. The spacing used in the experiment was $0.4 \mathrm{~m}$ between plants, $0.6 \mathrm{~m}$ between simple rows, and $0.9 \mathrm{~m}$ between double rows. Plant training for growth orientation was performed by vertical shoot positioning, using cross-pickets with $1.80 \mathrm{~m}$ height and 4 wires, with plants tied with cotton strings.

The application of pure biofertilizer in the soil was performed weekly by manually applying $200 \mathrm{~mL}^{\text {plant }}{ }^{-1}$, beginning at sowing and kept until 28 days after sowing (at $0,7,14,21$, and 28 DAS), thus completing the final volume of $1 \mathrm{~L}$. plant ${ }^{-1}$.

The foliar application of the biofertilizer began seven days after sowing with the aid of a manual sprayer, applied until the liquid dripped from the leaves. The applications were performed in weekly intervals at 7, 14, 21 , and 28 days after sowing, totaling four applications. Before the application, the biofertilizer was filtered to avoid the clogging of the spraying nozzle and diluted in water.

The irrigation system used in the whole cycle was by dripping, composed of a plastic tube per planting bed and self-compensating emitters with a $2 \mathrm{~L} \mathrm{~h}^{-1}$ flow, spaced by $0.40 \mathrm{~m}$, turned on twice a day (at 8:00 a.m. and 4 a.m.). During the conduction of the experiment, no treatments were required for disease control. For the control of the cucumber fruit borer, the biological 
insecticide Dipel (Bacillus thuringiensis) was sprayed three times a day during the fructification stage.

The harvests were performed two times a week, beginning at 43 days after sowing and extending through a 40-day period (83 DAS), totaling 12 harvests. At the end of each harvest, the fruits were initially separated into nonmarketable and marketable. Afterward, the marketable fruits were classified into two quality categories: class 1, with 15 to $20 \mathrm{~cm}$ length and a straight cylindrical shape, and class 2, with 10 to $15 \mathrm{~cm}$ length and a slight tortuosity or sharp tip, considered variable and mild defects, respectively.

According to the cucumber classification (HORTIBRASIL, 2009), tortuosity is a variable defect, defined based on the ratio between the shortest distance from the apex to the base of the fruit $(A)$ and its external length (B). A/B ratios below or equal to 0.85 are considered very crooked, thus constituting severe defects. In this perspective, the crooked cucumbers classified as class 2 presented A/B ratios between 0.85 and 0.95 , thus constituting slight defects.

After the classification, the fruits were counted and weighed in a digital analytical balance for the obtainment of the following variables: number of class 1 marketable fruits, class 2 marketable fruits, total marketable fruits (class 1 + class 2), and total fruits (marketable + non-marketable) per plant, as well as the mean mass and yield of the fruits of classes 1, 2, marketable, and total fruits. The mean fruit diameter and length of the marketable fruits of classes 1 and 2 were also evaluated, with the aid of a digital pachymeter and a metric tape.

At the end of the harvest period, the data were subjected to the verification of the presence of outliers by Grubbs's test, to the test of normality of residues by the Shapiro-Wilk test, and to the homogeneity of variances by Bartlett's test. The data referring to the variables of mean mass, yield, and the number of class 2 fruits per plant were transformed into root square. After the verification of assumptions, the analysis of variance was performed by the F-test, and the quantitative treatments that presented significant effects at $5 \%$ of probability were subjected to regression analysis, considering the linear or quadratic equations of more significance.

\section{Results and Discussion}

There was no significant interaction ( $p>0.05$ ) between the application of biofertilizer via foliar spraying and via soil for all analyzed variables. The number of fruits of classes 1, 2, and the marketable fruits produced per plant were influenced $(p<0.05)$ by the isolated effect of the concentrations of biofertilizer applied via foliar spraying.

The number of marketable fruits per plant, which comprises classes 1 and 2, presented a quadratic response to the increase in biofertilizer concentrations, reaching a maximum value of 4.18 fruits plant ${ }^{-1}$ at the 3 $\%$ concentration (Figure 1). The highest number of class 1 marketable fruits produced per plant (3.71 fruits plant ${ }^{-1}$ ) was obtained at the $3.05 \%$ concentration of biofertilizer (Figure 1). These fruits generally presented a higher marketable value, especially in the conventional markets of vegetables, were selection is more careful, although food waste is higher. In this study, the fruits of this class corresponded to $77.36 \%$ of the total productivity.

In a protected environment, the Japanese cucumber hybrid (Kouki Fl) produced up to 11.7 marketable fruits per plant with the application of biofertilizer based on manure at the concentration of $15 \%$, via fertigation (Antonio et al., 2017). This difference between studies can be attributed to several factors, such as the genotype (Sediyama et al., 2014a), since these are different hybrids, as well as the climatic conditions and technological levels employed, which influence the different responses of flowering and fructification (Filgueira, 2013).

The mean mass of total fruits increased $(p<0.05)$ with the increment in the concentrations of biofertilizer, reaching a maximum of $242.2 \mathrm{~g} \mathrm{fruit}^{-1}$ at the concentration of $3 \%$, reducing above this value (Figure 2)

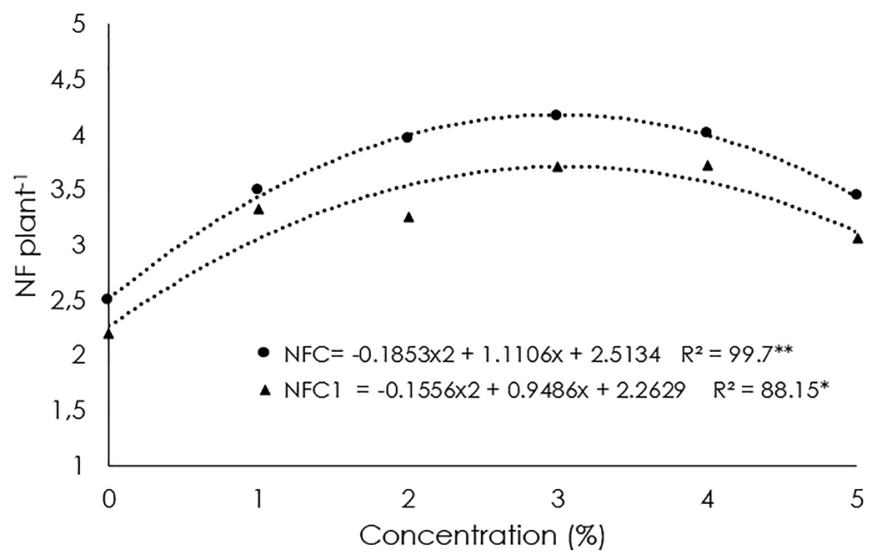

Figure 1. Number of marketable fruits (NFC) and number of class 1 marketable fruits (NFC 1 ) per cucumber plant as a function of the concentrations of biofertilizer applied via foliar spraying.

The decreases observed in all variables from the concentration of $3 \%$ may be directly related to some phytotoxicity effect in the plants that received higher concentrations of biofertilizer, probably caused by nutritional and metabolic imbalances. This occurs since more concentrated dilutions of biofertilizer present a 


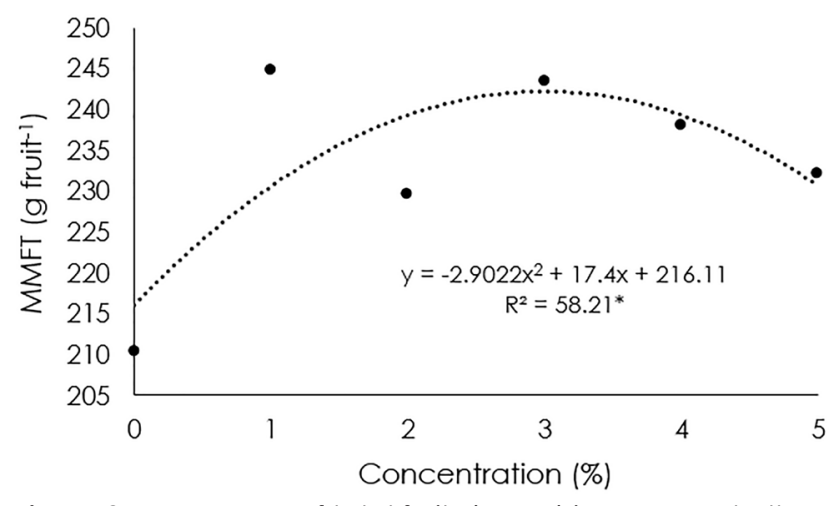

Figure 2. Mean mass of total fruits (MMFT) in response to the concentrations of biofertilizer applied via foliar spraying.

higher load of microorganisms and metabolites, causing energetic shifts in the plants for the activation of defense mechanisms to the detriment of growth and vegetative development (Medeiros \& Lopes, 2006), or even making the consumption of the product unfeasible, as observed for lettuce (Tavella et al., 2012). High concentrations of biofertilizer can also cause the increase of electrical conductivity, resulting in the reduction of vegetative growth, as observed by Gomes Junior et al. (2011) in the cultivation of cherry tomato, in which the application of $5 \%$ of biofertilizer reduced the stem dry matter.

The mean masses of marketable fruits were not influenced $(p>0.05)$ by the application of biofertilizer via soil and/or foliar spraying (Table 1).

Nevertheless, the mean mass of class 1 fruits

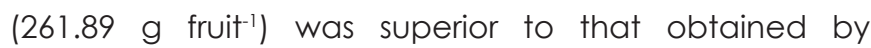
Sediyama et al. (2014a), who obtained $146.90 \mathrm{~g}$ per marketable fruit for the cucumber hybrid Aladdin grown in an organic system and harvested upon reaching 20 $\mathrm{cm}$ of length. The mean length and diameter of the class 1 fruits was $18.10 \mathrm{~cm}$ and $45.51 \mathrm{~mm}$, respectively. In turn, class 2 presented a mean fruit length of $11.80 \mathrm{~cm}$ and a diameter of $39.76 \mathrm{~mm}$. These variables did not respond ( $p>0.05$ ) to the application of biofertilizer via soil and foliar spraying (Table 1).

Table 1. Mean masses of class 1 marketable fruits $\left(M M F C_{1}\right)$, class 2 marketable fruits $\left(M_{M F C_{2}}\right)$, and marketable fruits (MMFC); mean lengths and diameters of the fruits of classes $1\left(\mathrm{CMFC}_{1}\right.$; $\left.\mathrm{DMFC}_{1}\right)$ and $2\left(\mathrm{CMFC}_{2} ; \mathrm{DMFC}_{2}\right)$ as a function of the concentrations of biofertilizer applied via foliar spraying in cucumber.

\begin{tabular}{|c|c|c|c|c|c|c|c|}
\hline \multirow{3}{*}{$\begin{array}{c}\text { Concentration } \\
\text { (\%) }\end{array}$} & \multicolumn{7}{|c|}{ Means } \\
\hline & MMFC $_{1}$ & $\mathrm{MMFC}_{2}$ & MMFC & $\mathrm{CMFC}_{1}$ & $\mathrm{CMFC}_{2}$ & $\mathrm{DMFC}_{1}$ & $\mathrm{DMFC}_{2}$ \\
\hline & & \multicolumn{2}{|c|}{ (g fruit $\left.{ }^{-1}\right)$} & \multicolumn{2}{|c|}{$(\mathrm{cm})$} & \multicolumn{2}{|c|}{$(\mathrm{mm})$} \\
\hline 0 & 253.66 & 109.67 & 235.33 & 17.65 & 11.26 & 46.50 & 34.87 \\
\hline 1 & 261.52 & 106.69 & 256.46 & 17.94 & 9.34 & 40.65 & 38.98 \\
\hline 2 & 259.99 & 156.36 & 241.11 & 18.19 & 13.01 & 46.47 & 43.65 \\
\hline 3 & 271.27 & 177.53 & 258.08 & 18.26 & 14.00 & 46.64 & 44.28 \\
\hline 4 & 266.30 & 135.28 & 256.49 & 18.31 & 12.01 & 46.82 & 39.32 \\
\hline 5 & 258.64 & 145.76 & 249.59 & 18.26 & 11.20 & 45.99 & 37.49 \\
\hline General mean & 261.89 & 138.55 & 249.51 & 18.10 & 11.80 & 45.51 & 39.76 \\
\hline C.V (\%) & 6.83 & 41.27 & 8.35 & 3.43 & 36.98 & 15.02 & 31.69 \\
\hline $\mathrm{F}_{\text {block }}$ & $2.381^{\mathrm{ns}}$ & $1.798^{\mathrm{ns}}$ & $4.749^{\mathrm{ns}}$ & $2.422^{\mathrm{ns}}$ & $1.474^{\mathrm{ns}}$ & $1.073^{\mathrm{ns}}$ & $0.542^{\mathrm{ns}}$ \\
\hline$F_{\text {treatment }}$ & $0.950^{\mathrm{ns}}$ & $1.834^{\mathrm{ns}}$ & $1.629 \mathrm{~ns}$ & $1.338^{\mathrm{ns}}$ & $1.099 \mathrm{~ns}$ & $0.985^{\mathrm{ns}}$ & 0.659 ns \\
\hline
\end{tabular}

The marketable and total yields responded $(p<0.05)$ to the foliar application of growing concentrations of biofertilizer. The yield of marketable fruits (class $1+$ class 2) responded in a quadratic manner to the increase in the concentrations of biofertilizer, with a maximum yield of $35.79+$ ha $^{-1}$ when applying $3.03 \%$ of biofertilizer (Figure 3).

This yield was superior to that observed by Souza et al. (2020) in the organic cultivation under direct sunlight of the ginoic-parthenocarpic cucumber hybrid Nagai, using seedlings produced with $798 \mathrm{~cm}^{3}$ of substrate $(24$ t ha $^{-1}$ ), and similar to that obtained by Silva et al. (2011) for the Aladdin hybrid $\left(37.55 \dagger\right.$ ha $\left.^{-1}\right)$ grown under organic cultivation in the rainy season of the Cerrado biome. On the other hand, Sediyama et al. (2014a), evaluating the effect of types of pruning and different cucumber hybrids, obtained a marketable yield of $40.16 \mathrm{tha}^{-1}$ for the Aladdin

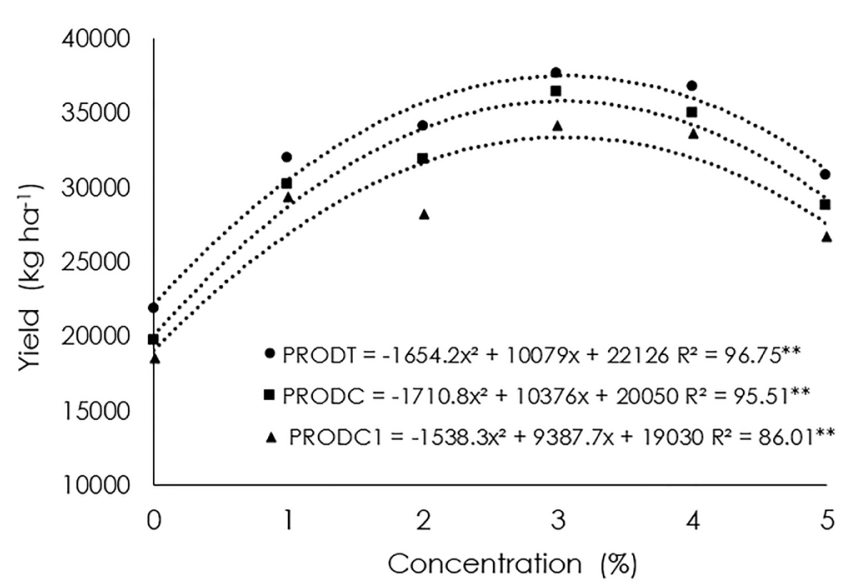

Figure 3. Yields of total (PRODT), marketable (PRODC), and class 1 marketable fruits (PRODC1) as a function of the concentrations of biofertilizer applied via foliar spraying in the cucumber crop via foliar spraying. 
hybrid, in organic cultivation.

The yield of class 1 marketable fruits also responded in a quadratic manner to the increase in the concentrations, with an increment of $75.26 \%$ in relation to the control treatment $\left(19.03 \mathrm{tha}^{-1}\right)$, in which the $3.05 \%$ concentration of biofertilizer promoted the maximum yield of $33.35 \mathrm{tha}^{-1}$ (Figure 3). Similarly, the $3.05 \%$ concentration of biofertilizer increased $(p<0.05)$ the yield of total fruits $(37.48$ $t_{h a^{-1}}$ ), regardless of the application of pure biofertilizer in the soil (Figure 3).

The number of class 2 fruits per plant and the yield of class 2 fruits responded to the application of biofertilizer via foliar spraying $(p<0.05)$, although their equations were not adjusted and their means are presented in Table 2.

Table 2. Mean number of class 2 fruits per plant $\left(\mathrm{NFC}_{2}\right)$ and mean yield of class 2 fruits (PRODC2) as a function of the application of concentrations of biofertilizer via foliar spraying in cucumber.

\begin{tabular}{|c|c|c|}
\hline \multirow{2}{*}{ Concentration (\%) } & \multicolumn{2}{|c|}{ Means } \\
\hline & $\mathrm{NFC}_{2}\left(\mathrm{NF}\right.$ plant $^{-1}$ ) & $\mathrm{PRODC}_{2}\left(\mathrm{~kg} \mathrm{ha}^{-1}\right)$ \\
\hline 0 & 0.29 & $1,196.88$ \\
\hline 1 & 0.16 & 871.50 \\
\hline 2 & 0.71 & $3,714.13$ \\
\hline 3 & 0.40 & $2,237.25$ \\
\hline 4 & 0.29 & $1,363.75$ \\
\hline 5 & 0.40 & $2,079.25$ \\
\hline General mean & 0.37 & $1,910.5$ \\
\hline C.V (\%) & 48.3 & 47.7 \\
\hline $\mathrm{F}_{\text {block }}$ & $0.340^{\text {ns }}$ & $0.126^{\mathrm{ns}}$ \\
\hline $\mathrm{F}_{\text {treatment }}$ & $3.679^{* *}$ & $4.141^{* *}$ \\
\hline
\end{tabular}

These variables presented crooked fruits and with a sharp tip, a disorder that usually occurs in fruits that develop in the extremities of the plants, whereas fruit tortuosity may occur due to imbalanced fertilization, especially with $\mathrm{N}$ and $\mathrm{K}$, being commonly observed in the field (Carvalho et al., 2013). In this study, a rate of only $10.08 \%$ of class 2 marketable fruits was verified, in relation to the total fruit production.

There was no significant difference $(p>0.05)$ between the absence and presence of the application of pure biofertilizer in the soil, for all evaluated variables. The application of biofertilizer in the soil is a common practice in agriculture, being usually performed as base fertilization, days or months before sowing (Galbiatti et al., 2011). The effect of the pure biofertilizer in the soil may probably be significant in the long term through the improvement of the physical, chemical, and biological characteristics of the soil, therefore requiring new studies to evaluate greater volumes and frequencies of application. Furthermore, the organic and chemical fertilization performed in the planting beds may have been sufficient for the crop to express is productive potential and have consequently limited the effect of the biofertilizer applied in the soil

The efficiency of the application via foliar spraying on the productive performance of the cucumber crop is justified by the faster absorption and accumulation of the macronutrients provided by the biofertilizer through the leaves. The results obtained corroborate those by Araújo et al. (2007) and Silva et al. (2012), in which they verified the superiority of the foliar application of biofertilizer in the marketable yields of bell pepper (Capsicum annuum) and yam (Dioscorea caynensis), respectively when associated with the use of bovine manure in the soil.

It is worth noting that, in the literature, most existing studies are limited to formulations composed of animal manure, whereas the biofertilizers obtained through plant residues are not approached and assessed, which complicates the performing of comparisons with other studies.

It is also worth noting that, in this study, there was no need for disease and pest control except the three applications of Bacillus thuringiensis to control the cucumber fruit borer (Diaphania nitidalis). This scenario may have been influenced by the application of biofertilizer for being a biological product that also assists in the control of pests and diseases (Araújo Neto \& Ferreira, 2019, Rodrigues et al., 2016). However, further studies are required to assess the microbiological composition of the biofertilizer, as well as for the verification of its action of phytosanitary control.

\section{Conclusions}

The application of pure biofertilizer in the soil does not replace the organo-mineral fertilization in the yield and quality of cucumber grown under cultivation system.

The biofertilizer applied on the leaves increases the number of marketable fruits per plant, the mean fruit mass, and the total and marketable cucumber crop yields.

The biofertilizer applied via foliar spraying, at the concentration of $3 \%$, is efficient in incrementing the cucumber crop yield.

\section{References}

Aguiar, A.V.M., Cavalcante, L.F., Salva, R.M., Dantas, T.A.G., Santos, E.C. 2017. Effect of biofertilization on yellow passion fruit production and fruit quality. Revista Caatinga 30: 136-148.

Antonio, I.C., Cardoso, M.O., Berni, R.F., Kano, C. 2017. Uso de biofertilizer na adubação complementar do pepino sob ambiente protegido. Embrapa Amazônia Ocidental, Manaus, Brazil. $20 \mathrm{p}$. 
Araújo Neto, S.E., Ferreira, R.L.F. 2019. Agricultura ecológica tropical. Clube de autores, Rio Branco, Brazil. $169 \mathrm{p}$.

Araújo, E.N., Oliveira, A.P., Lourival, F.C., Pereira, W.E., Brito, N.M., Neves, C.M.L., Silva, E.E. 2007. Produção do pimentão adubado com esterco bovino e biofertilizante. Revista Brasileira de Engenharia Agrícola e Ambiental 11: 466-470.

Carvalho, A.D.F., Amaro, G.B., Lopes, J.F., Vilela, N.J.V., Michereff Filho, M., Andrade, R. 2013. A cultura do pepino. Embrapa Hortaliças, Brasília, Brazil. 18 p.

Cavalcante, L.F., Bezerra, F.T.C., Souto, A.G.L., Bezerra, M.A.F., Lima, G.S., Gheyi, H.R., Ferreira, J.F.S., BeckmannCavalcante, M.Z. 2019. Biofertilizers in horticultural crops. Comunicata Scientiae 10: 415-428.

Chiconato, D.A., Simoni, F., Galbiatti, J.A., Franco, C.F., Caramelo, A.D. 2013. Resposta da alface à aplicação de biofertilizante sob dois níveis de irrigação. Bioscience Journal 29: 392-399.

Dutra, K.O.G., Cavalcante, S.N., Vieira, I.G.S., Costa, J.C.F., Andrade, R.A. 2016. Adubação orgânica no cultivo da melancieira cv. Crimson Sweet. Revista Brasileira de Agropecuária Sustentável 6: 34-45.

Filgueira, F.A.R. 2013. Novo manual de olericultura: agrotecnologia moderna na produção e comercialização de hortaliças. UFV, Viçosa, Brazil. 421 p.

Galbiatti, J.A., Silva, F.G., Franco, C.F., Caramelo, A.D. 2011. Desenvolvimento do feijoeiro sob o uso de biofertilizante e adubação mineral. Engenharia Agrícola 31: 167-177.

Ghosh, R., Mukhopadhyay, A., Mandal, N.C. 2015. Biological control of fruit-rot of jackfruit by rhizobacteria and food grade lactic acid bacteria. Biological Control 83: 29-36.

Gomes Junior, J., Silva, A.J.N., Silva, L.L.M., Souza, F.T., Silva, J.R. 2011 . Crescimento e produtividade de tomateiros do grupo cereja em função da aplicação de biofertilizante líquido e fundo micorrízico arbuscular. Revista Brasileira de Ciências Agrárias 6: 627-633.

Gomes, L.P., Oliveira, F.A., Bezerra, F.M.S., Lima, L.A., Costa, L.P., Guedes, R.A.A. 2015. Produtividade de cultivares de maxixeiro em função de doses de biofertilizante. Revista Agro@mbiente On-line 9: 275-283.

HORTIBRASIL. Instituto Brasileiro de Qualidade em Horticultura. 2009. http://www.hortibrasil.org.br/ classificacao/pepino/arquivos/categoria.html. <Access on 06 Dec. 2019>

IBGE. Instituto Brasileiro de Geografia e Estatística. 2017. https://sidra.ibge.gov.br/tabela/6619\#resultado. <Access on 17 Dec. 2019>

INMET. Instituto Nacional de Meteorologia. 2019. http:// www.inmet.gov.br/portal/ index.php? r=bdmep/bdmep. <Access on 11 Jun. 2019>

Kumar, M., Kathayat, K., Singh, S.K., Singh, L., Singh, T. 2018.
Influence of bio-fertilizers application on growth, yield and quality attributes of cucumber (Cucumis sativus L.): a review. Plant Archives 18: 2329-2334.

Medeiros, M.B., Lopes, J.S. 2006. Biofertilizantes líquidos e sustentabilidade agrícola. Bahia Agrícola 7: 24-26.

Mellek, J.E., Dieckow, J., Silva, V.L., Favaretto, N., Pauletti, V., Vezzani, F.M., Souza, J.L.M. 2010. Dairy liquid manure and no-tillage: physical and hydraulic properties and carbon stocks in a Cambisol of Southern Brazil. Soil \& Tillage Research 110: 69-76.

Nobile, F.O., Galbiatti, A.J., Muraishi, R.I., Spadoni, T.B. 2012. Biofertilizante e adubação mineral no desenvolvimento da cultura da cebola (Allium cepa L.) irrigado com duas lâminas de água. Nucleus 9: 27-34.

Nunes, J.A.S., Nunes, J.C., Silva, J.A., Oliveira, A.P., Cavalcante, L.F., Oresca, D., Silva, O.P.R. 2018. Influence of spacing and application of biofertilizer on growth and yield of okra (Abelmoschus esculentus (L.) Moe-h). African Journal of Biotechnology 17: 17-23.

Oliveira, J.R., Gomes, R.L.F., Araújo, A.S.F., Marini, F.S., Lopes, J.B., Araújo, R.M. 2014. Estado nutricional e produção da pimenteira com uso de biofertilizantes líquidos. Revista Brasileira de Engenharia Agrícola e Ambiental 18: 1241-1246.

Rampelotto, P.H., Ferreira, A.S., Barboza, A.D.M., Roesch, L.F.W. 2013. Changes in diversity, abundance, and structure of soil bacterial communities in Brazilian savana under different land use systems. Microbial Ecology 66: 593-607.

Rodrigues, V.W.B., Bueno, T.V., Tebaldi, N.D. 2016. Biofertilizers in the control of tomato bacterial spot (Xanthomonas spp.). Summa Phytopathologica 42: 94-96.

Santos, A.J., Monção, O.P., Ribeiro, P.R.C.C., Amaral, R.F., Reis, T.C. 2013. Efeito da aplicação foliar de biofertilizer na cultura da alface crespa veneranda (Lactuca sativa L.). Enciclopédia Biosfera 9: 11 140-1149.

Santos, A.P.G., Viana, T.V.A., Sousa, G.G.S., Gomes-do-Ó, L.M., Azevedo, B.M., Santos, A.M. 2014. Produtividade e qualidade de frutos do meloeiro em função de tipos e doses de biofertilizante. Horticultura Brasileira 32: 409-416.

Santos, J.L.G., Gondim, A.R.O., Lima Neto, J.V., Silva, E.A. 2017. Cultivo da cenoura submetida à aplicação de doses de biofertilizante. Revista Verde de Agroecologia e Desenvolvimento Sustentável 12: 55-60.

Santos, R.A., Gomes, F.S., Guariz, H.R., Porto, T.B.S. 2019. Produção e qualidade do meloeiro em sistema orgânico de produção no semiárido baiano. Revista Verde de Agroecologia e Desenvolvimento Sustentável 14: 397405.

Sediyama, M.A.N., Nascimento, J.L.M., Lopes, I.P.C., Lima, P.C., Vidigal, S.M. 2014a. Tipos de poda em pepino dos grupos aodai, japonês e caipira. Horticultura Brasileira 32: 491-496.

Sediyama, M.A.N., Santos, I.C., Lima, P.C. 2014b. Cultivo 
de hortaliças no sistema orgânico. Revista Ceres 61: 829837.

Silva, G.P.P., Resende, F.V., Souza, R.B., Albuquerque, J.O., Vidal, M.C., Sousa, J.M.M. 2011. Avaliação de híbridos e adubação para o cultivo orgânico do pepino no período chuvoso do cerrado. Horticultura Brasileira 29: 4601-4608.

Silva, J.A., Oliveira, A.P., Alves, G.S., Cavalcante, L.F., Oliveira, A.N.P., Araújo, M.A.M. 2012. Rendimento do inhame adubado com esterco e biofertilizante no solo e na folha. Revista Brasileira de Engenharia Agrícola e Ambiental 16: 253-257.

Souza, A.O., Araújo Neto, S.E., Ferreira, R.L.F. 2020. Produtividade de pepino em cultivo orgânico utilizando mudas produzidas com diferentes volumes de substrato. Scientia Naturalis 2: 1-9.

Tavella, L.B., Salino, A.J.S., Campos, P.A., Araújo Neto, S.E., Ferreira, R.L.F. 2012. Aplicação foliar de produtos agroecológicos no desempenho agronômico da alface. ACSA - Agropecuária Científica no Semi-Árido 8: 23-27.

Wang, M., Chen, S., Han, Y., Chen, L., Wang, D. 2019. Responses of soil aggregates and bacterial communities to soil-Pb immobilization induced by biofertilizer. Chemosphere 220: 828-836.

Conflict of Interest Statement: The authors declare that the research was conducted in the absence of any commercial or financial relationships that could be construed as a potential conflict of interest.

All the contents of this journal, except where otherwise noted, is licensed under a Creative Commons Attribution License attribuition-type BY. 